\title{
Effects of Drying on the Physicochemical and Functional Properties of Green Banana (Musa sapientum) Flour and Development of Baked Product
}

\author{
S. M. Asif-Ul-Alam, M. Z. Islam", M. M. Hoque, K. Monalisa \\ Department of Food Engineering and Tea Technology, Shahjalal University of Science \& Technology, Sylhet-3114, Bangladesh \\ *Corresponding author: zohurulislam.engg@gmail.com
}

Received March 18, 2014; Revised April 11, 2014; Accepted August 11, 2014

\begin{abstract}
This study investigated the effects of hot air drying and freeze drying methods on physicochemical and functional properties of green banana (Musa sapientum) flour and incorporated biscuits. Both freeze and hot air dried green banana flour was replaced by wheat flour with different degrees of substitutions including $0,10,15,20 \%$ and subjected to proximate analysis and sensory evaluation. The results of this study showed that freeze drying method retained high amount of protein, fat, ash and fiber content in green banana flour than hot air drying method. The moisture content was high in hot air dried banana flour than freeze dried flour. That's why the water holding capacity of hot air dried banana flour was high. The freeze dried banana flour had the higher foaming capacity (10.48\%) as compared with hot air dried banana flour (8.61\%). As the concentration of banana flour increased the spread ratio of biscuits decreased. The addition of increasing level of banana flour had higher ash, fiber, carbohydrate, calcium, phosphorus, iron and zinc content while protein and fat content found lower in the biscuits. In sensory analysis, 5\% freeze dried biscuits hold the highest score in color, texture and overall acceptability; and 10\% hot air dried secured highest score in flavor.
\end{abstract}

Keywords: banana flour, supplemented biscuits, freeze drying, hot air drying, functional properties, physicochemical properties, sensory quality

Cite This Article: S. M. Asif-Ul-Alam, M. Z. Islam, M. M. Hoque, and K. Monalisa, “Effects of Drying on the Physicochemical and Functional Properties of Green Banana (Musa sapientum) Flour and Development of Baked Product.” American Journal of Food Science and Technology, vol. 2, no. 4 (2014): 128-133. doi: 10.12691/ajfst-2-4-4.

\section{Introduction}

Green Banana flour (BF) is an alternative to reducing banana wastes and it is also a low cost material for food industry [1]. According to the available reports, green banana is rich in starch and its flour contains 61.3-76.5 $\mathrm{g} / 100 \mathrm{~g}$ of starch (dry weight) and has high fiber content (6.3-15.5 g/100 g) (dry weight) [2]. It has been reported that a high dietary fiber intake has beneficial effects on human health [3]. As a result banana flour can be added into the baked product due to different flavor and texture. Most banana flour, produced from the green unripe fruit is sun dried or dried in crude ovens, under these conditions the quality of the product is very variable [3]. Natural sun drying reduce the qualitative and quantitative value of the dried products. Due to difficulties in controlling the drying conditions, specially temperature and time, "browning effect" (discoloration) was occurred [3]. Currently the market prefers high quality dried products with good reconstitution properties and excellent sensory attributes. Biscuits are one of the most widely consumed food products in all over the world. Biscuits are basically made from wheat flour, sugar, milk powder, baking powder and water. Traditional biscuits are claimed to lack other essential nutritional components such as dietary fiber, vitamins and minerals which are lost during wheat flour refinement. Thus, biscuits which represent a major enduse of wheat is suitable for enhancing health after incorporating sources of fiber and essential nutrients [5]. The development of new products is a strategic area of the food industry. Consumers are interested in those foods which have the traditional nutritional aspects and which provide health benefits by regular ingestion. The major objectives of this study are i) to evaluate and compare the physicochemical and functional properties of flours produced from unripe banana fruit by the methods of hot air drying and freeze drying. ii) to develop dietary fiberenriched baked product such as biscuit by incorporation of banana flour with wheat flour in the formulations. iii) to study the effect of various levels of banana flour on quality, composition and sensory properties of prepared biscuits.

\section{Materials and Methods}

The experiment was conducted in the Department of Food Engineering and Tea Technology, Shahjalal University of Science and Technology, Sylhet, Bangladesh, 2013. 


\subsection{Materials}

Fresh green bananas (Musa sapientum) were collected from local market. Then the sample was dried by using a hot air drier and freeze drier. The dried sample was turned into flour by using a blender. Other materials like refined wheat flour, sugar, fat etc. required for biscuit making were purchased from local markets.

\subsection{Biscuit Formulation}

The basic formulations used for preparation of biscuits are outlined in Table 1. The biscuits were prepared with the incorporation of hot air dried and freeze dried banana flour in $0,5,10,15$ and 20\% concentration with wheat flour. The pre-weighed ingredients were mixed properly. The baking chemicals and sugar were dissolved in water. A mixture of raw materials was added to obtain a uniform dough and the dough was allowed to relax for 15 minutes before rolling out. The dough was then kneaded and rolled to a uniform thickness of $3 \mathrm{~mm}$.

Table 1. Basic formulation of biscuit

\begin{tabular}{|c|c|}
\hline Ingredients $^{*}$ & Quantity (g) \\
\hline Wheat flour $^{*}$ & 100 \\
\hline Dalda & 40 \\
\hline Sugar & 40 \\
\hline Salt & 0.5 \\
\hline Milk powder & 5 \\
\hline Water & 20 \\
\hline Baking powder & 5 \\
\hline
\end{tabular}

*Wheat flour was replaced with various levels of hot air dried and freeze dried banana flour by 5\%, 10\%, 15\% and 20\% in the formulation.

The rolled out dough was allowed to relax for 5 minutes. Then the biscuits were cut out with round biscuit cutter of $3.5 \mathrm{~cm}$ diameter. The cut out biscuits were placed on either greased pans or paper lined pans about 0.5 inches apart and the biscuits were allowed to rest in the pan about 10 minutes and baked at $220^{\circ} \mathrm{C}$ for $10-15$ minutes, cooled to ambient temperature and packed in high density polyethylene bags.

\subsection{Proximate Composition}

Banana flours were analyzed for their physicochemical and functional properties. Particularly, the functional properties are required for the formulation of value added composite bakery products.

\subsection{Physicochemical Properties}

Protein (micro- Kjeldahl, $\times$ 6.25), fat (Folch method), moisture, ash and crude fiber were determined by the AOAC (2004) [6] methods. The carbohydrate content was calculated by subtraction method. Calcium (Ca), Phosphorus (P), Iron (Fe) and Zinc (Zn) determined by using Atomic Absorption Spectrophotometer (Thermoscientific iCE 3000) and the calorific value was calculated.

\subsection{Functional Properties}

\subsubsection{Water and Oil Absorption Capacity}

The water and oil absorption capacities were determined by the method of Sosulski et al., 1986 [7]. The sample (1.0 g) was mixed with $10 \mathrm{ml}$ distilled water or refined soybean oil, kept at ambient temperature for 30 min and centrifuged for $10 \mathrm{~min}$ at $2000 \times \mathrm{g}$. Water or oil absorption capacity was expressed as percent water or oil bound per gram of the sample.

\subsubsection{Bulk Density}

The bulk density was determined according to the method described by Okaka and Potter [8]. The sample (50 g) was put into a $100 \mathrm{ml}$ graduated cylinder and tapped 20-30 times. The bulk density was calculated as weight per unit volume of sample.

\subsubsection{Swelling Capacity}

The method of Okaka and Potter [8] with some modifications was used for determining the swelling capacity. The sample filled up to $10 \mathrm{ml}$ mark in a $100 \mathrm{ml}$ graduated cylinder was added with water to adjust total volume to $50 \mathrm{ml}$. The top of the graduated cylinder was tightly covered and mixed by inverting the cylinder. The suspension was inverted again after $2 \mathrm{~min}$ and allowed to stand for further $30 \mathrm{~min}$. The volume occupied by the sample was taken after $30 \mathrm{~min}$.

\subsubsection{Foaming Capacity}

Foaming capacity and foaming stability were determined as described by Narayana and Narasinga Rao (1982) [9] with slight modifications. Sample (1.0 g) was added to $50 \mathrm{ml}$ distilled water at $30 \pm 20{ }^{\circ} \mathrm{C}$ in a graduated cylinder. The suspension was mixed and shaken for $5 \mathrm{~min}$ to foam. The volume of the foam after whipping for 30 Sec was expressed as foaming capacity

\subsubsection{Emulsifying Activity}

Emulsifying activity was determined as described by Okaka and Potter [8]. The sample (0.5 g) was added to 10 $\mathrm{ml}$ distilled water and shaking the mixture for $3 \mathrm{~min}$ in a centrifuge tube. The mixture was made up to $12.5 \mathrm{ml}$ by adding oil and homogenized for $3 \mathrm{~min}$. The resulting emulsion was centrifuged at 2000 RPM for 5 min and then the emulsion volume was measured.

\subsection{Physical Analysis of Biscuits}

Diameter of biscuits was measured by laying three biscuit edge to edge with the help of a scale rotating them $90^{\circ}$ and again measuring the diameter of three biscuits (cm) and then taking an average value. Thickness as measured by stacking three biscuits on top of each other and taking average thickness (cm). Weight of biscuits was measured as average of values of three individual biscuits with the help of digital weighing balance. Spread ratio was calculated by dividing the average value of the diameter by average value of thickness of biscuits. Percent spread was calculated by dividing the spread ratio of supplemented biscuits with a spread ratio of control biscuits and multiplying by 100 .

\subsection{Sensory Analysis of Biscuits}

Biscuit samples were analyzed for sensory characteristics. Sensory quality characteristics were evaluated by a panel of 10 semi-trained members using a 9-point Hedonic scale where 9 = like extremely; 8 = like very much; 7 = like moderately; 6 = like slightly; 5 = neither like nor dislike; 4 = dislike slightly; 3 = dislike moderately; 2 = dislike very much; 1 = dislike extremely. 
The biscuits were evaluated for their color, flavor, texture and overall acceptability.

\subsection{Statistical Analysis}

Data was analyzed using analysis of variance (ANOVA) to determine significant differences among the various samples in triplicate using the software, statistical package for social science (SPSS) version 11.00 SPSS inc., Chicago, IL, USA at the 0.05 level.

\section{Results and Discussion}

\subsection{Proximate Composition of Banana Flours}

Table 2 shows that the proximate composition of the banana flour samples. A noticeable difference was observed in moisture, ash, crude fiber, carbohydrate, protein, calcium, phosphorus, iron and zinc content of hot air dried and freeze dried banana flour. Freeze dried banana flour showed the highest value in all examined parameters except in moisture. In addition, textural quality, chemical and biochemical reactions, as well as microbial growth rates are greatly affected by the moisture content of food products [10]. The research article [11] concluded that banana pseudo-stem flour is a potential functional food ingredient for products containing high dietary fiber. According to [12] moisture, fat and ash content of modified banana flour were significantly lower than banana flour. This is due to heat, moisture, and autoclave treatment of modified banana flour that had an impact on the physicochemical properties of flour.

Table 2. Proximate composition of banana flours

\begin{tabular}{|c|c|c|}
\hline Component & $\begin{array}{c}\text { Hot air dried } \\
\text { banana flour }\end{array}$ & $\begin{array}{c}\text { Freeze dried banana } \\
\text { flour }\end{array}$ \\
\hline Moisture (\%) & $14.31 \pm 0.6$ & $9.33 \pm 0.06$ \\
\hline Protein (\%) & $3.19 \pm 0.08$ & $3.95 \pm 0.2$ \\
\hline Fat (\%) & $0.50 \pm 0.05$ & $1.31 \pm 0.07$ \\
\hline Ash (\%) & $1.20 \pm 0.09$ & $2.55 \pm 0.07$ \\
\hline Fiber (\%) & $4.2 \pm 0.1$ & $4.9 \pm 0.3$ \\
\hline Carbohydrate (\%) & $80.80 \pm 0.5$ & $82.86 \pm 0.4$ \\
\hline Calcium (mg) & $32 \pm 0.2$ & $35 \pm 0.1$ \\
\hline Phosphorus (mg) & $93 \pm 0.4$ & $94 \pm 0.3$ \\
\hline Iron (mg) & $2.6 \pm 0.1$ & $2.7 \pm 0.1$ \\
\hline Zinc (mg) & $0.18 \pm 0.1$ & $0.19 \pm 0.1$ \\
\hline
\end{tabular}

Results are expressed as mean values and standard deviation of three replicates

\subsection{Functional Properties of Flours}

The functional properties of flours play an important role in the manufacturing of bakery products. The hot air dried banana flour and freeze dried banana flour were analyzed for their functional properties. Table 3 shows the various functional properties of flours. The water holding capacity of freeze dried flour was found lower than that of hot air dried flour. The oil absorption capacity (OAC) of hot air dried flour was higher than that of freeze dried flour. The oil absorption capacity (OAC) of flour is equally important as it improves the mouth feel and retains the flavor. The swelling capacities of hot air dried flour and freeze dried flour are 2.6 and 6.01 (g pastelg dry sample) respectively. The foaming capacity of freeze dried flour was higher than that of hot air dried flour. Foaming capacity is assumed to be dependent on the configuration of protein molecules. Flexible proteins have good foaming capacity, but a highly ordered globular molecule gives low foam's ability [13]. Emulsifying activity was also higher in hot air dried flour. The bulk density of hot air dried flour was $0.53 \mathrm{~g} / \mathrm{ml}$, higher than that of the freeze dried flour $(0.36 \mathrm{~g} / \mathrm{ml})$. The yield of freeze dried flour $(25.22 \%)$ was higher than that of hot air dried flour (22.21\%).

Table 3. Functional properties of flours

\begin{tabular}{|c|c|c|}
\hline Property & $\begin{array}{c}\text { Hot air dried } \\
\text { banana flour }\end{array}$ & $\begin{array}{c}\text { Freeze dried } \\
\text { banana flour }\end{array}$ \\
\hline $\begin{array}{c}\text { Water holding capacity (g } \\
\text { water g dry sample) }\end{array}$ & $3.01 \pm 0.28$ & $2.26 \pm 0.11$ \\
\hline $\begin{array}{c}\text { Oil holding capacity (g oil } \backslash \mathrm{g} \\
\text { dry sample) }\end{array}$ & $0.75 \pm 0.08$ & $0.52 \pm 0.06$ \\
\hline $\begin{array}{c}\text { Swelling capacity (g paste } \backslash \mathrm{g} \\
\text { dry sample) }\end{array}$ & $2.6 \pm 0.45$ & $6.01 \pm 0.09$ \\
\hline Foaming capacity\% & $8.61 \pm 0.28$ & $10.48 \pm 0.08$ \\
\hline Emulsifying activity\% & $1.67 \pm 0.06$ & $0.8 \pm 0.04$ \\
\hline Bulk density (g\ml) & $0.53 \pm 0.03$ & $0.36 \pm 0.03$ \\
\hline Yield\% & $22.21 \pm 0.80$ & $25.22 \pm 0.22$ \\
\hline
\end{tabular}

Results are expressed as mean values and standard deviation of three replicates

\subsection{Proximate Composition of Biscuits}

The proximate composition of biscuits is shown in Table 4. In the present study several types of biscuits, one containing $0 \%$ banana flour and the other containing different amount of hot air and freeze dried banana flour were prepared and analyzed for their composition. Moisture content of freeze dried banana flour incorporated biscuits was less than the hot air dried banana flour biscuits, due to less moisture content of freeze dried banana flour. Protein content of banana flour incorporated biscuits was less than the control ( $0 \%$ banana flour), because banana flour contain less amount of protein. According to Bonazzi C. \& Dumoulin E [14] the biological value of dried proteins varies with the drying procedure. Prolonged exposures to high temperatures can affect the functional properties or render the protein less useful in the diet. The fat content of control biscuits was $20.5 \%$ and it decreased to $17.21 \%$ in $20 \%$ hot air dried banana flour biscuits and $18.51 \%$ in $20 \%$ freeze dried banana flour biscuits. The fiber content of control biscuits was $0.97 \%$, which increased to $2.86 \%$ in $20 \%$ hot air dried banana flour biscuits and $3.05 \%$ in $20 \%$ freeze dried banana flour biscuits. This was due to the high fiber content in banana flour, and freeze dried banana flour contain higher amount of fiber than hot air dried flour. According to [15] total dietary fiber content of the wholemeal bread with $7 \%$ banana peel flour was higher (14.4\%) than the control sample (11.3\%). The carbohydrate content was determined by difference method was found to be higher in $20 \%$ hot air dried banana flour biscuits. Beside this, Calcium (Ca), Phosphorus (P), Iron (Fe) and Zinc ( $\mathrm{Zn}$ ) increased with increasing \% of banana flour incorporation. Freeze dried banana flour biscuits showed higher amounts of observing minerals than hot air dried. From the standpoint of nutritional quality the sample with $0 \%$ banana flour had higher protein and fat content. But the fiber content was high in $20 \%$ freeze dried banana flour biscuits. Results showed that $5 \%$ freeze dried banana flour biscuits had the highest amount of energy (488.58 Kcal), and 20\% hot air dried banana flour biscuits had the lowest amount of energy (473.37 Kcal). The moisture, ash, protein, fat and total carbohydrate contents of biscuits were more or less 
similar to those reported by [16]. Banana flour and

formulations at $20 \%$ substitution [12]. modified banana flour was found to be acceptable in bread

Table 4. Proximate composition of biscuits

\begin{tabular}{|c|c|c|c|c|c|c|c|c|c|}
\hline \multirow{2}{*}{ Parameter } & Control & \multicolumn{3}{|c|}{ Biscuit with hot air dried banana flour } & \multicolumn{3}{c|}{ Biscuit with freeze dried banana flour } \\
\cline { 2 - 10 } & S0 & S1 & S2 & S3 & S4 & S5 & S6 & S7 & S8 \\
\hline Moisture (\%) & $3.22 \pm 0.2$ & $2.71 \pm 0.2$ & $2.50 \pm 0.1$ & $2.15 \pm 0.1$ & $2.00 \pm 0.0$ & $2.11 \pm 0.2$ & $1.96 \pm 0.15$ & $1.74 \pm 0.2$ & $1.66 \pm 0.1$ \\
\hline Protein (\%) & $9.37 \pm 0.01$ & $9.03 \pm 0.2$ & $8.75 \pm 0.1$ & $8.31 \pm 0.2$ & $7.98 \pm 0.4$ & $9.12 \pm 0.01$ & $8.95 \pm 0.00$ & $8.41 \pm 0.14$ & $8.13 \pm 0.24$ \\
\hline Fat (\%) & $20.5 \pm 0.1$ & $19.09 \pm 0.15$ & $18.78 \pm 0.04$ & $18.11 \pm 0.08$ & $17.21 \pm 0.1$ & $20.10 \pm 0.29$ & $19.85 \pm 0.1$ & $19.03 \pm 0.02$ & $18.51 \pm 0.5$ \\
\hline Ash (\%) & $0.60 \pm 0.01$ & $0.79 \pm 0.04$ & $0.98 \pm 0.3$ & $1.10 \pm 0.2$ & $1.17 \pm 0.08$ & $0.87 \pm 0.04$ & $1.04 \pm 0.25$ & $1.21 \pm 0.31$ & $1.30 \pm 0.1$ \\
\hline Fiber (\%) & $0.97 \pm 0.01$ & $2.01 \pm 0.05$ & $2.39 \pm 0.04$ & $2.71 \pm 0.1$ & $2.86 \pm 0.16$ & $2.21 \pm 0.2$ & $2.57 \pm 0.25$ & $2.90 \pm 0.4$ & $3.05 \pm 0.17$ \\
\hline Carbohydrate (\%) & $66.31 \pm 0.1$ & $68.38 \pm 0.01$ & $68.99 \pm 0.3$ & $70.33 \pm 0.17$ & $71.64 \pm 0.2$ & $67.8 \pm 0.04$ & $68.2 \pm 0.08$ & $69.61 \pm 0.01$ & $70.4 \pm 0.03$ \\
\hline Energy (Kcal) & $486.94 \pm 2.0$ & $481.45 \pm 2$ & $479.98 \pm 3$ & $477.55 \pm 2$ & $473.37 \pm 2$ & $488.58 \pm 4$ & $487.25 \pm 4$ & $483.35 \pm 3$ & $480.71 \pm 2$ \\
\hline Calcium (mg) & $18.35 \pm 0.02$ & $25 \pm 0.03$ & $28 \pm 0.05$ & $31 \pm 0.04$ & $34 \pm 0.04$ & $26 \pm 0.03$ & $28 \pm 0.03$ & $33 \pm 0.02$ & $34 \pm 0.03$ \\
\hline Phosphorus (mg) & $113.65 \pm 0.2$ & $170 \pm 0.4$ & $212 \pm 0.3$ & $290 \pm 0.5$ & $365 \pm 0.4$ & $177 \pm 0.2$ & $215 \pm 0.3$ & $299 \pm 0.3$ & $371 \pm 0.3$ \\
\hline Iron (m) & $1.50 \pm 0.01$ & $2.01 \pm 0.01$ & $2.52 \pm 0.02$ & $3.00 \pm 0.01$ & $3.5 \pm 0.01$ & $2.02 \pm 0.01$ & $2.52 \pm 0.01$ & $3.02 \pm 0.01$ & $3.62 \pm 0.01$ \\
\hline Zinc (mg) & $0.84 \pm 0.01$ & $1.23 \pm 0.01$ & $1.72 \pm 0.02$ & $2.11 \pm 0.01$ & $2.54 \pm 0.01$ & $1.25 \pm 0.01$ & $1.74 \pm 0.01$ & $2.12 \pm 0.01$ & $2.55 \pm 0.01$ \\
\hline
\end{tabular}
$\mathrm{S}_{0}=0 \% \mathrm{BF}$ (control), $\mathrm{S}_{1}=5 \% \mathrm{ABF}, \mathrm{S}_{2}=10 \% \mathrm{ABF}, \mathrm{S}_{3}=15 \% \mathrm{ABF}, \mathrm{S}_{4}=20 \% \mathrm{ABF}, \mathrm{S}_{5}=5 \% \mathrm{FBF}, \mathrm{S}_{6}=10 \% \mathrm{FBF}, \mathrm{S}_{7}=15 \% \mathrm{FBF}, \mathrm{S}_{8}=20 \% \mathrm{FBF}$. The values are mean \pm S.D of three independent determinations.

Table 5. Physical properties of biscuits

\begin{tabular}{|c|c|c|c|c|c|c|c|c|c|}
\hline \multirow{2}{*}{ Parameter } & Control & \multicolumn{4}{|c|}{ Biscuit with hot air dried banana flour } & \multicolumn{4}{|c|}{ Biscuit with freeze dried banana flour } \\
\hline & $\mathrm{S}_{0}$ & $\mathrm{~S}_{1}$ & $\mathrm{~S}_{2}$ & $\mathrm{~S}_{3}$ & $\mathrm{~S}_{4}$ & $\mathrm{~S}_{5}$ & $\mathrm{~S}_{6}$ & $\mathrm{~S}_{7}$ & $\mathrm{~S}_{8}$ \\
\hline Diameter $(\mathrm{cm})$ & $4.38 \pm 0.01$ & $4.21 \pm 0.06$ & $4.21 \pm 0.03$ & $4.27 \pm 0.18$ & $4.28 \pm 0.16$ & $4.09 \pm 0.06$ & $4.14 \pm 0.16$ & $4.17 \pm 0.02$ & $4.19 \pm 0.15$ \\
\hline Thickness $(\mathrm{cm})$ & $0.45 \pm 0.15$ & $0.51 \pm 0.04$ & $0.52 \pm 0.07$ & $0.58 \pm 0.02$ & $0.59 \pm 0.02$ & $0.42 \pm 0.01$ & $0.44 \pm 0.01$ & $0.48 \pm 0.02$ & $0.49 \pm 0.02$ \\
\hline Weight (g) & $4.52 \pm 0.08$ & $5.74 \pm 0.59$ & $6.05 \pm 0.60$ & $6.23 \pm 0.38$ & $6.45 \pm 0.49$ & $4.40 \pm 0.06$ & $4.54 \pm 0.24$ & $5.08 \pm 0.05$ & $5.5 \pm 0.09$ \\
\hline Spread ratio & $9.73 \pm 0.21$ & $8.25 \pm 0.75$ & $8.09 \pm 0.62$ & $7.36 \pm 0.12$ & $7.25 \pm 0.43$ & $9.73 \pm 0.33$ & $9.40 \pm 0.29$ & $8.68 \pm 0.42$ & $8.55 \pm 0.61$ \\
\hline \% spread & 100 & 84.78 & 83.14 & 75.64 & 74.51 & 100 & 96.60 & 89.20 & 87.87 \\
\hline
\end{tabular}

$\mathrm{S}_{0}=0 \%$ BF (control), $\mathrm{S}_{1}=5 \%$ ABF, $\mathrm{S}_{2}=10 \%$ ABF, $\mathrm{S}_{3}=15 \%$ ABF, $\mathrm{S}_{4}=20 \%$ ABF, $\mathrm{S}_{5}=5 \%$ FBF, $\mathrm{S}_{6}=10 \%$ FBF, $\mathrm{S}_{7}=15 \%$ FBF, $\mathrm{S}_{8}=20 \%$ FBF. The values are mean \pm S.D of three independent determinations

Table 6. Mean sensory scores of formulating biscuits

\begin{tabular}{|c|c|c|c|c|c|}
\hline Parameter & Biscuit type & Original order of mean & Biscuit type & Ranked order of mean & Sig. $(\mathrm{p}<0.05)$ \\
\hline \multirow{10}{*}{ Color } & $\mathrm{S}_{0}$ & $7.30^{\mathrm{a}}$ & $\mathrm{S}_{0}$ & $7.30^{\mathrm{a}}$ & \multirow{5}{*}{0.006} \\
\hline & $\mathrm{S}_{1}$ & $7.10^{\mathrm{a}}$ & $\mathrm{S}_{1}$ & $7.10^{\mathrm{a}}$ & \\
\hline & $\mathrm{S}_{2}$ & $6.60^{\mathrm{ab}}$ & $\mathrm{S}_{2}$ & $6.60^{\mathrm{ab}}$ & \\
\hline & $\mathrm{S}_{3}$ & $6.30^{\mathrm{b}}$ & $\mathrm{S}_{3}$ & $6.30^{\mathrm{b}}$ & \\
\hline & $\mathrm{S}_{4}$ & $6.20^{b}$ & $\mathrm{~S}_{4}$ & $6.20^{\mathrm{b}}$ & \\
\hline & $\mathrm{S}_{0}$ & $7.30^{\mathrm{a}}$ & $\mathrm{S}_{0}$ & $7.30^{\mathrm{a}}$ & \multirow{5}{*}{0.008} \\
\hline & $\mathrm{S}_{5}$ & $7.20^{\mathrm{a}}$ & $\mathrm{S}_{5}$ & $7.20^{\mathrm{a}}$ & \\
\hline & $\mathrm{S}_{6}$ & $7.10^{\mathrm{a}}$ & $\mathrm{S}_{6}$ & $7.10^{\mathrm{a}}$ & \\
\hline & $\mathrm{S}_{7}$ & $6.60^{\mathrm{ab}}$ & $\mathrm{S}_{7}$ & $6.60^{\mathrm{ab}}$ & \\
\hline & $\mathrm{S}_{8}$ & $6.20^{b}$ & $\mathrm{~S}_{8}$ & $6.20^{\mathrm{b}}$ & \\
\hline \multirow{10}{*}{ Flavor } & $\mathrm{S}_{0}$ & $7.80^{\mathrm{a}}$ & $\mathrm{S}_{0}$ & $7.80^{\mathrm{a}}$ & \multirow{5}{*}{0.001} \\
\hline & $\mathrm{S}_{1}$ & $7.00^{b}$ & $\mathrm{~S}_{2}$ & $7.20^{\mathrm{ab}}$ & \\
\hline & $\mathrm{S}_{2}$ & $7.20^{\mathrm{ab}}$ & $\mathrm{S}_{1}$ & $7.00^{\mathrm{b}}$ & \\
\hline & $\mathrm{S}_{3}$ & $6.70^{\mathrm{bc}}$ & $\mathrm{S}_{3}$ & $6.70^{\mathrm{bc}}$ & \\
\hline & $\mathrm{S}_{4}$ & $6.20^{\mathrm{C}}$ & $\mathrm{S}_{4}$ & $6.20^{\mathrm{C}}$ & \\
\hline & $\mathrm{S}_{0}$ & $7.10^{\mathrm{a}}$ & $\mathrm{S}_{0}$ & $7.81^{\mathrm{a}}$ & \multirow{5}{*}{0.888} \\
\hline & $\mathrm{S}_{5}$ & $7.10^{\mathrm{a}}$ & $\mathrm{S}_{6}$ & $7.30^{\mathrm{a}}$ & \\
\hline & $\mathrm{S}_{6}$ & $7.30^{\mathrm{a}}$ & $\mathrm{S}_{5}$ & $7.10^{\mathrm{a}}$ & \\
\hline & $\mathrm{S}_{7}$ & $7.00^{\mathrm{a}}$ & $\mathrm{S}_{7}$ & $7.00^{\mathrm{a}}$ & \\
\hline & $\mathrm{S}_{8}$ & $7.00^{\mathrm{a}}$ & $\mathrm{S}_{8}$ & $7.00^{\mathrm{a}}$ & \\
\hline \multirow{10}{*}{ Texture } & $\mathrm{S}_{0}$ & $7.80^{\mathrm{a}}$ & $\mathrm{S}_{0}$ & $7.81^{\mathrm{a}}$ & \multirow{5}{*}{0.003} \\
\hline & $\mathrm{S}_{1}$ & $6.60^{b}$ & $\mathrm{~S}_{1}$ & $6.60^{b}$ & \\
\hline & $\mathrm{S}_{2}$ & $6.50^{\mathrm{b}}$ & $\mathrm{S}_{2}$ & $6.50^{\mathrm{b}}$ & \\
\hline & $\mathrm{S}_{3}$ & $6.30^{b}$ & $\mathrm{~S}_{3}$ & $6.30^{b}$ & \\
\hline & $\mathrm{S}_{4}$ & $6.20^{b}$ & $\mathrm{~S}_{4}$ & $6.20^{b}$ & \\
\hline & $\mathrm{S}_{0}$ & $7.81^{\mathrm{a}}$ & $\mathrm{S}_{0}$ & $7.81^{\mathrm{a}}$ & \multirow{5}{*}{0.002} \\
\hline & $\mathrm{S}_{5}$ & $7.54^{\mathrm{a}}$ & $\mathrm{S}_{5}$ & $7.54^{\mathrm{a}}$ & \\
\hline & $\mathrm{S}_{6}$ & $6.62^{b}$ & $\mathrm{~S}_{6}$ & $6.62^{b}$ & \\
\hline & $\mathrm{S}_{7}$ & $6.20^{\mathrm{b}}$ & $\mathrm{S}_{7}$ & $6.20^{\mathrm{b}}$ & \\
\hline & $\mathrm{S}_{8}$ & $6.62^{b}$ & $\mathrm{~S}_{8}$ & $6.62^{b}$ & \\
\hline \multirow{10}{*}{$\begin{array}{c}\text { Overall } \\
\text { Acceptability }\end{array}$} & $\mathrm{S}_{0}$ & $7.60^{\mathrm{a}}$ & $\mathrm{S}_{0}$ & $7.63^{\mathrm{a}}$ & \multirow{5}{*}{0.013} \\
\hline & $\mathrm{S}_{1}$ & $6.20^{c}$ & $\mathrm{~S}_{2}$ & $7.20^{\mathrm{ab}}$ & \\
\hline & $\mathrm{S}_{2}$ & $7.20^{\mathrm{ab}}$ & $\mathrm{S}_{3}$ & $6.80^{\mathrm{abc}}$ & \\
\hline & $\mathrm{S}_{3}$ & $6.80^{\mathrm{abc}}$ & $\mathrm{S}_{4}$ & $6.70^{\mathrm{bc}}$ & \\
\hline & $\mathrm{S}_{4}$ & $6.70^{\mathrm{bc}}$ & $\mathrm{S}_{1}$ & $6.20^{\mathrm{C}}$ & \\
\hline & $\mathrm{S}_{0}$ & $7.60^{\mathrm{a}}$ & $\mathrm{S}_{0}$ & $7.60^{\mathrm{a}}$ & \multirow{5}{*}{0.001} \\
\hline & $\mathrm{S}_{5}$ & $7.30^{\mathrm{ab}}$ & $\mathrm{S}_{5}$ & $7.30^{\mathrm{ab}}$ & \\
\hline & $\mathrm{S}_{6}$ & $6.70^{\mathrm{bc}}$ & $\mathrm{S}_{6}$ & $6.70^{\mathrm{bc}}$ & \\
\hline & $\mathrm{S}_{7}$ & $6.20^{c}$ & $\mathrm{~S}_{7}$ & $6.20^{c}$ & \\
\hline & $\mathrm{S}_{8}$ & $6.20^{\mathrm{C}}$ & $\mathrm{S}_{8}$ & $6.20^{c}$ & \\
\hline
\end{tabular}

The values are mean \pm S.D of three independent determinations. The means with different superscripts in a row differ significantly (p $\leq 0.05$ ). $\mathrm{S}_{0}=0 \%$ $\mathrm{BF}$ (control), $\mathrm{S}_{1}=5 \% \mathrm{ABF}, \mathrm{S}_{2}=10 \% \mathrm{ABF}, \mathrm{S}_{3}=15 \% \mathrm{ABF}, \mathrm{S}_{4}=20 \% \mathrm{ABF}, \mathrm{S}_{5}=5 \% \mathrm{FBF}, \mathrm{S}_{6}=10 \% \mathrm{FBF}, \mathrm{S}_{7}=15 \% \mathrm{FBF}, \mathrm{S}_{8}=20 \% \mathrm{FBF}$. 


\subsection{Physical Properties of Biscuits}

The physical properties of biscuits prepared from hot air dried banana flour and freeze dried banana flour are shown in Table 5. Among the biscuit samples, the control biscuit had the highest diameter. Freeze dried flour biscuits had less diameter than hot air dried flour biscuits. The diameter of biscuit sample decreased from 4.38-4.28 cm with $0-20 \%$ hot air dried banana flour respectively. The diameter of biscuit sample decreased from 4.38-4.19 cm with $0-20 \%$ freeze dried banana flour respectively. The thickness of biscuit ranges from $0.42-0.59 \mathrm{~cm}$. The hot air dried flour biscuits were thicker than freeze dried flour biscuits. Biscuits which contained 20\% hot air dried flour had a higher thickness $(0.59 \mathrm{~cm})$, and $5 \%$ freeze dried flour biscuits had a lowest thickness $(0.42 \mathrm{~cm})$. The change in diameter and thickness were reflected in spread ratio and \% spread of biscuits. The spread ratio and percent spread of control biscuits were 9.73 and 100 respectively. Spread ratio and percent spread decreased with the addition of banana flour. But these parameters decreased highly in hot air dried flour biscuits than freeze dried flour biscuits. Other researchers also reported reduction in the spread ratio when soy flour and fenugreek flour were substituted for wheat flour [17]. At 0-20\% addition hot air dried flour, the weight of the biscuit increased gradually from 4.52 to $6.45 \mathrm{~g}$. But freeze dried flour biscuits were lighter in weight than hot air dried flour biscuits. 5\% freeze dried flour biscuit had less weight (4.40 g) than control biscuits (4.52 g).

\subsection{Sensory Characteristics of Biscuits}

The sensory characteristics of biscuits prepared from hot air dried banana flour and freeze dried banana flour are shown in Table 6. The analysis indicated that there were significant differences in color, flavor, texture and overall acceptability between control biscuits and biscuits containing hot air and freeze dried banana flour ( $\mathrm{p} \leq 0.05)$ except flavor in freeze dried biscuits. With the increasing level of banana flour in the formulation, the sensory score for color, texture and overall acceptability of biscuits decreased. The texture of control biscuits and 10\% freeze dried banana flour biscuits were statistically similar. By comparing the parameters (color, flavor, texture and overall acceptability) between freeze dried banana flour and hot air dried banana flour biscuits 5\% freeze dried banana flour biscuits was superior in color and texture, and $10 \%$ freeze dried banana flour biscuits were superior in flavor. In overall acceptability $10 \%$ hot air and 5\% freeze dried banana flour containing biscuits attained higher score.

\section{Conclusion}

The present study demonstrated that different drying techniques for the preparation of green banana flour noticeably change the nutritional and functional properties of banana flour. Nutritional composition was slightly higher in freeze dried banana flour than hot air dried banana flour. The study showed that green banana flour can be successfully incorporated in wheat flour biscuits up to a level of $20 \%$ to yield biscuits of enhanced nutritional quality with acceptable sensory attributes. However the hot air dried green banana flour incorporated biscuits had less nutritional and sensory attributes than freeze dried green banana flour incorporated biscuits. This was due to high retention of nutrient in freeze dried banana flour. Hence, development and utilization of such functional foods will not only improve the nutritional status of the population, but also helps those suffering from digestion disorder. The finding of this study may help generate technology to diversify the use of green banana flour by the food processing enterprises, specially baking industries. More studies should be conducted to investigate the possibility of using green banana flour as an ingredient in other food products in order to increase applications of such value-added food ingredient. To improve the nutritional quality of green banana flourbased biscuits, high protein soy flour or nut pieces or flavor can be incorporated in the formulation.

\section{Acknowledgements}

The authors gratefully acknowledge to the Department of Food Engineering \& Tea Technology, Shahjalal University of Science \& Technology, Sylhet, Bangladesh for providing the facilities to carry out this research work.

\section{Reference}

[1] Zhang P., Whistler R. L., BeMiller J. N. \& Hamaker B.R. (2005). Banana starch: production, physical properties and digestibility - a review. Carbohydrate Polymers 59: 443-458.

[2] Juarez-Garcia E., Agama-Acevedo E., Sayago-Ayerdi S.G., Rodriguez-Ambriz S.L. \& Bello-Perez L.A. (2006). Composition, digestibility and application in breadmaking of banana flour. Plant Foods for Human Nutrition 61: 131-137.

[3] P. Kaddumukasa, W. kyamuhangire, J. Muyonga \& F.I. Muranga. (2005). The effect of drying methods on the quality of green banana flour. African Crop Science Conference Proceedings, 7: 1267-1271

[4] Guillon, F., and Champ, M 2000. Structural and physical properties of dietary fibres, an consequences of processing on human physiology. Journal of Food Research International in the Tropics, 33, 233-245.

[5] Chong L. C. \& Noor Aziah A.A. (2008). Influence of Partial Substitution of Wheat Flour with Banana (Musa paradisiaca var. Awak) Flour on the Physico-Chemical and Sensory Characteristics of Doughnuts. International Food Research Journal 15 (2): 119124.

[6] AOAC (2004). Official method of Analysis of the Association of official Analytical chemists. 15th Ed., Washington. USA.

[7] Sosulski F.W., Garratt M.O. \& Slinkard A.E. (1976). Functional properties of ten legume flours. International Journal of Food Science and Technology 9: 66-69.

[8] Okaka J. C. \& Potter N.N. (1977). Functional and storage properties of cowpea-wheat flour blends in bread making. Journal of Food Science 42: 828-833.

[9] Narayana K. \& Narasinga Rao M.S. (1982). Functional properties of raw and heat processed winged bean flour. Journal of Food Science 42: 534-538.

[10] Aurore G., Parfait B., Fahrasmane L. (2009). Banana raw materials for making processed food products. Trends in Food science and Technology 20: 78-91.

[11] Noor Aziah A. A., Ho L.H., Baharin A., Rajeev B., Cheng L.C., Mohamad Nasir M.I., (2011). Chemical and functional properties of the native banana (Musa acuminate balbisiana Colla cv. Awak) pseudo stem and pseudo stem tender core flours. Food Chemistry 128: 748-753.

[12] I. Zowariah \& A.A. Noor Aziah (2009). Physicochemical properties of wheat breads substituted with banana flour and modified banana flour. J. Tropic. Agric. And Fd. Sc. 37 (1): 33-42. 
[13] Graham, D.E. and Philips, M.C. 1976. The conformation of proteins at the air-water interface and their role in stabilizing foam. In Akers, R.J. (Ed.) New York: Academic Press. Foams, p. 237255.

[14] Bonazzi C. \& Dumoulin E. (2011) Quality Changes in Food Materials as Influenced By Drying Processes. Modern Drying Technology Volume 3: Product Quality and Formulation, $1^{\text {st }}$ edition

[15] Nasution Z., Lim R.Y. and Wan Hafiz W.Z.S (2012). Banana peel flour: an alternative ingredient for wholemeal bread. UMT $11^{\text {th }}$ International Annual Symposium on Sustainability Science and
Management. $09^{\text {th }}-11^{\text {th }}$ July 2012, Terengganu, Malaysia. pp 682687.

[16] Kabirullah M., Rukonuddin A., Khan S.A., Mosharef H., Mojibur R.A.K.M., Azizul M.I.K. \& Moazzam M.H. (1995). Analysis of Nutrients of Bangladeshi Processed Foods. Part 1-Different types of biscuits. Bangladesh journal of Scientific and Industrial Research 30 (1): 121.

[17] Hooda S. \& Jood S. (2005). Organoleptic and nutritional evaluation of wheat biscuits supplemented with untreated and treated fenugreek flour. Food Chemistry 90: 427-435. 